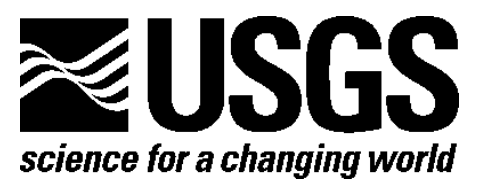

\title{
Soil Data for a Thermokarst Bog and the Surrounding Permafrost Plateau Forest, Located at Bonanza Creek Long Term Ecological Research Site, Interior Alaska
}

By Kristen L. Manies, Christopher C. Fuller, Miriam C. Jones, Mark P. Waldrop, and John P. McGeehin

Open-File Report 2016-1173

U.S. Department of the Interior

U.S. Geological Survey 


\section{U.S. Department of the Interior \\ SALLY JEWELL, Secretary}

\section{U.S. Geological Survey \\ Suzette M. Kimball, Director}

U.S. Geological Survey, Reston, Virginia: 2017

For more information on the USGS—-the Federal source for science about the Earth, its natural and living resources, natural hazards, and the environment-visit http://www.usgs.gov/ or call 1-888-ASK-USGS (1-888-275-8747).

For an overview of USGS information products, including maps, imagery, and publications, visit https://store.usgs.gov.

Any use of trade, firm, or product names is for descriptive purposes only and does not imply endorsement by the U.S. Government.

Although this information product, for the most part, is in the public domain, it also may contain copyrighted materials as noted in the text. Permission to reproduce copyrighted items must be secured from the copyright owner.

Suggested citation:

Manies, K.L., Fuller, C.C., Jones, M.C., Waldrop, M.P., and McGeehin, J.P., 2017, Soil data for a thermokarst bog and the surrounding permafrost plateau forest, located at Bonanza Creek Long Term Ecological Research Site, Interior Alaska: U.S. Geological Survey Open-File Report 2016-1173, 11 p., http://dx.doi.org/10.3133/ofr20161173. 


\section{Contents}

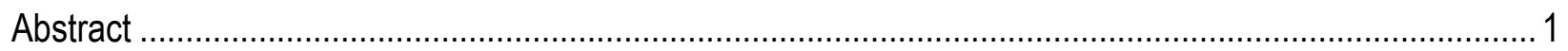

Introduction

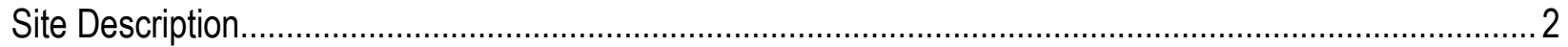

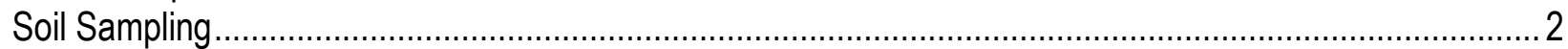

Soil-Sample Preparation and Drying........................................................................................... 4

Soil Laboratory Methods ......................................................................................................

Total Carbon, Total Nitrogen, $\delta^{13} \mathrm{C}$ Measurements ..................................................................... 5

Radiocarbon Measurements ................................................................................................

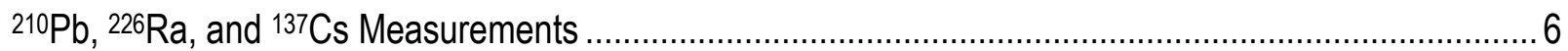

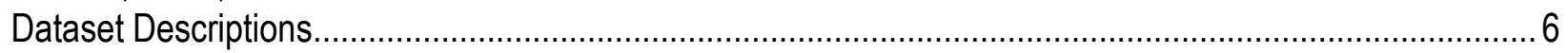

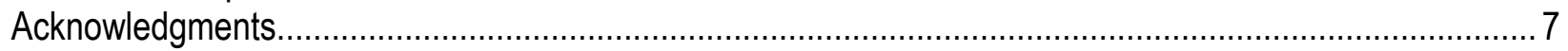

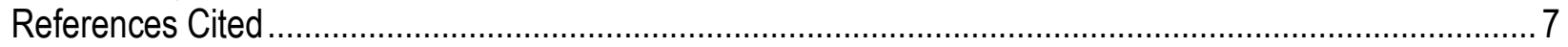

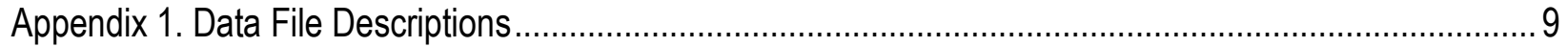

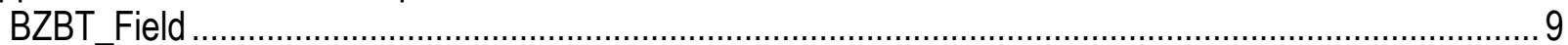

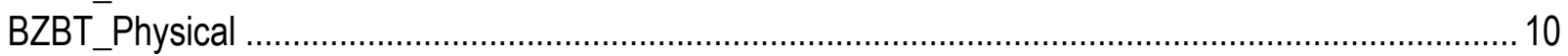

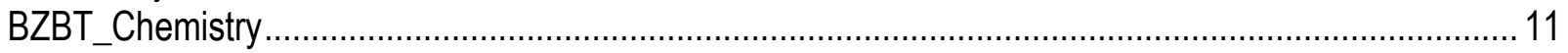

\section{Figures}

1. Map showing the location of samples: cores 1-3, 5, 7, and 9 were taken from within the thermokarst bog; cores 4,6 , and 11 were taken from the surrounding forested permafrost plateau ......................... 2

2. Photograph showing sampling with the frozen finger............................................................ 3

\section{Tables}

1. Statistics of analyses for working standards run on the Carlo Erba 1500, from 2012 to 2014, the time during which these samples were run. 


\section{Conversion Factors}

International System of Units to U.S. customary units

\begin{tabular}{|c|c|c|}
\hline Multiply & By & To obtain \\
\hline \multicolumn{3}{|c|}{ Length } \\
\hline centimeter $(\mathrm{cm})$ & 0.3937 & inch (in.) \\
\hline millimeter (mm) & 0.03937 & inch (in.) \\
\hline meter $(\mathrm{m})$ & 3.281 & foot (ft) \\
\hline meter $(\mathrm{m})$ & 1.094 & yard (yd) \\
\hline \multicolumn{3}{|c|}{ Area } \\
\hline square meter $\left(\mathrm{m}^{2}\right)$ & 10.76 & square foot $\left(\mathrm{ft}^{2}\right)$ \\
\hline \multicolumn{3}{|c|}{ Mass } \\
\hline gram $(\mathrm{g})$ & 0.03527 & ounce, avoirdupois (oz) \\
\hline kilogram $(\mathrm{kg})$ & 2.205 & pound avoirdupois (lb) \\
\hline
\end{tabular}

Temperature in degrees Celsius $\left({ }^{\circ} \mathrm{C}\right)$ may be converted to degrees Fahrenheit $\left({ }^{\circ} \mathrm{F}\right)$ as ${ }^{\circ} \mathrm{F}=\left(1.8 \times{ }^{\circ} \mathrm{C}\right)+32$.

\section{Datum}

Horizontal coordinate information is referenced to the World Geodetic System of 1984 (WGS84). 


\title{
Soil Data for a Thermokarst Bog and the Surrounding Permafrost Plateau Forest, Located at Bonanza Creek Long Term Ecological Research Site, Interior Alaska
}

\author{
By Kristen L. Manies, Christopher C. Fuller, Miriam C. Jones, Mark P. Waldrop, and John P. McGeehin
}

\begin{abstract}
Peatlands play an important role in boreal ecosystems, storing a large amount of soil organic carbon. In northern ecosystems, collapse-scar bogs (also known as thermokarst bogs) often form as the result of ground subsidence following permafrost thaw. To examine how ecosystem carbon balance changes with the loss of permafrost, we measured carbon and nitrogen storage within a thermokarst bog and the surrounding forest, which continues to have permafrost. These sites are a part of the Bonanza Creek Long Term Ecological Research (LTER) site and are located within Interior Alaska. Here, we report on methods used for core collection analysis as well as the cores' physical, chemical, and descriptive properties.
\end{abstract}

\section{Introduction}

Boreal soils, including peatlands, contain the largest proportion of soil carbon, as compared to other regions around the world (Kasischke, 2000; Tarnocai and others, 2009), and, therefore, play an important role in the global carbon cycle. Interior Alaska, which is part of the boreal region, contains discontinuous permafrost and a variety of ecosystems, including forests (with and without permafrost) and peatlands (Gallant and others, 1995). These peatlands store nearly 30 percent of the soil organic carbon found within this region (Hugelius and others, 2014), owing to the high rates of carbonhttp://www.bigsurcalifornia.org/restaurants.html (C) inputs through plant production and low rates of $\mathrm{C}$ loss, which are due to waterlogged soils and low soil temperatures (Camill and others, 2001). Bogs are peatlands that receive all or most of their water from precipitation and, thus, are acidic and low in nutrients. Permafrost thaw causing ground subsidence is called thermokarst. Thermokarst bogs form as the result of thawing permafrost when ice-rich forests with permafrost thaw and the ground surface subsides. When this process results in inundation by water, thermokarst bogs are formed, and the surrounding raised forest are known as forested permafrost plateaus.

To help compare $\mathrm{C}$ and nitrogen $(\mathrm{N})$ stocks in a thermokarst bog and the surrounding forested permafrost plateau, we measured physical, chemical, and descriptive soil properties from cores taken from each of these ecosystem types. These measurements were taken as part of a larger study examining changes in $\mathrm{C}$ balance as a forested permafrost plateau becomes a thermokarst bog and which mechanisms may be responsible for $\mathrm{C}$ storage and loss (see, for example, Neumann and others, 2016). 


\section{Site Description}

The thermokarst bog and forested permafrost plateau studied here are located approximately 30 $\mathrm{km}$ southwest of Fairbanks, Alaska, near the Tanana River (fig. 1; lat $64.696^{\circ}$ N., long $148.321^{\circ}$ W.). These sites are a part of the Bonanza Creek Long Term Ecological Research (LTER) program's network of sites. The forested permafrost plateau has an active layer (seasonally unfrozen) thickness that ranges between 50 and $90 \mathrm{~cm}$ (measured early October 2015). The majority of the trees are Picea mariana, although Larix laricina is found in open areas. The dominant understory vegetation is Vaccinium uliginosum, Vaccinium vitis-idaea, Calamagrostis canadensis, Eriophorum spp., Rhododendron tomentosum, and mosses such as Polytrichum strictum, Hylocomium splendens, and Sphagnum fuscum. The thermokarst bogs are dominated by Sphagnum riparium with some Carex aquatilis, Carex chordorrhiza, and Vaccinium oxycoccos Linnaeus. It has actively thawing margins, as indicated by "drunken" trees and dead Picea mariana trees located within the thermokarst feature. $\mathrm{CO}_{2}$ and $\mathrm{CH}_{4}$ flux measurements have been made at both sites annually using eddy covariance towers (Euskirchen and others, 2014), static chambers (Wickland and others, 2006), and automatic chambers (Mark Waldrop, U.S. Geological Survey, unpublished data).

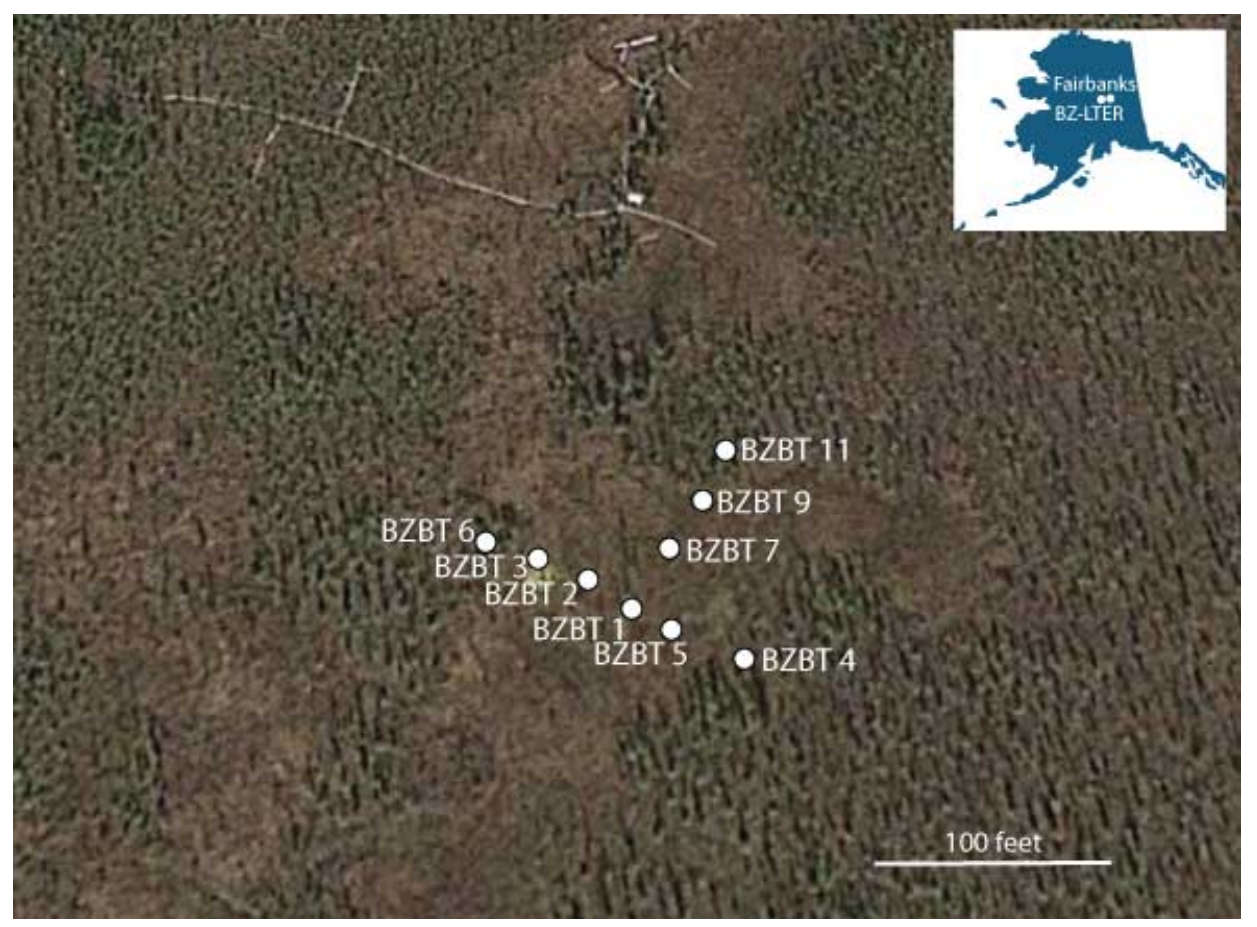

Figure 1. Map showing the location of samples: cores 1-3, 5, 7, and 9 were taken from within the thermokarst bog; cores 4, 6, and 11 were taken from the surrounding forested permafrost plateau. Inset: The location of the Bonanza Creek Long Term Ecological Research (BZ-LTER) within Alaska. The thermokarst bog studied here is affiliated with the LTER.

\section{Soil Sampling}

Soil cores were taken using two methods. The first method, with a Snow, Ice, and Permafrost Research Establishment (SIPRE) corer (7.6-cm diameter; Rand and Mellor, 1985), was used when the soil was frozen. These cores were from permafrost plateaus and the surface of 
the bog. Bog cores were taken in such a way as to provide depth and $\mathrm{C}$ storage information regarding both the center and edges of the bog. Coring locations were along two randomly placed transects - one which crossed the bog, the other which traversed from the center of the bog to the edge. Cores within the permafrost plateau were located at the approximate location where these transects entered the forest and were 1-3 $\mathrm{m}$ from the bog edge. These cores were taken in early spring and were returned to the lab frozen, where they were subsampled (usually of 2-cm thickness) using a bandsaw before further processing (see Soil-Sample Preparation and Drying section for processing information). SIPRE cores obtained from the bog did not reach mineral soil as there was over $50 \mathrm{~cm}$ of unfrozen peat below the frozen surface.

To sample the organic-mineral soil interface, additional cores for some, but not all, thermokarst bog cores were obtained during the summer using a "frozen finger." This coring method uses a thin-walled hollow tube $(\sim 6.5-\mathrm{cm}$ diameter $)$, sealed at one end, which is inserted into the ground until it hits mineral soil. A slurry of dry ice and alcohol is then poured into the corer, freezing the unfrozen material surrounding the corer to the outside (fig. 2). The corer is then removed from the bog and the exterior of the core is scraped to remove any large roots or material that stuck to the sample during removal. Then the "shell" of soil surrounding the core is divided (usually into 2- or 5-cm-thick bands) and removed from the corer. Samples from the two coring methods can then be combined to create continuous samples from the bog surface to the base of the peat and into the mineral soil. Additional cores taken within the same area were labeled to differentiate between the two methods (see Soil-Sample Preparation and Drying section for more information on labeling).

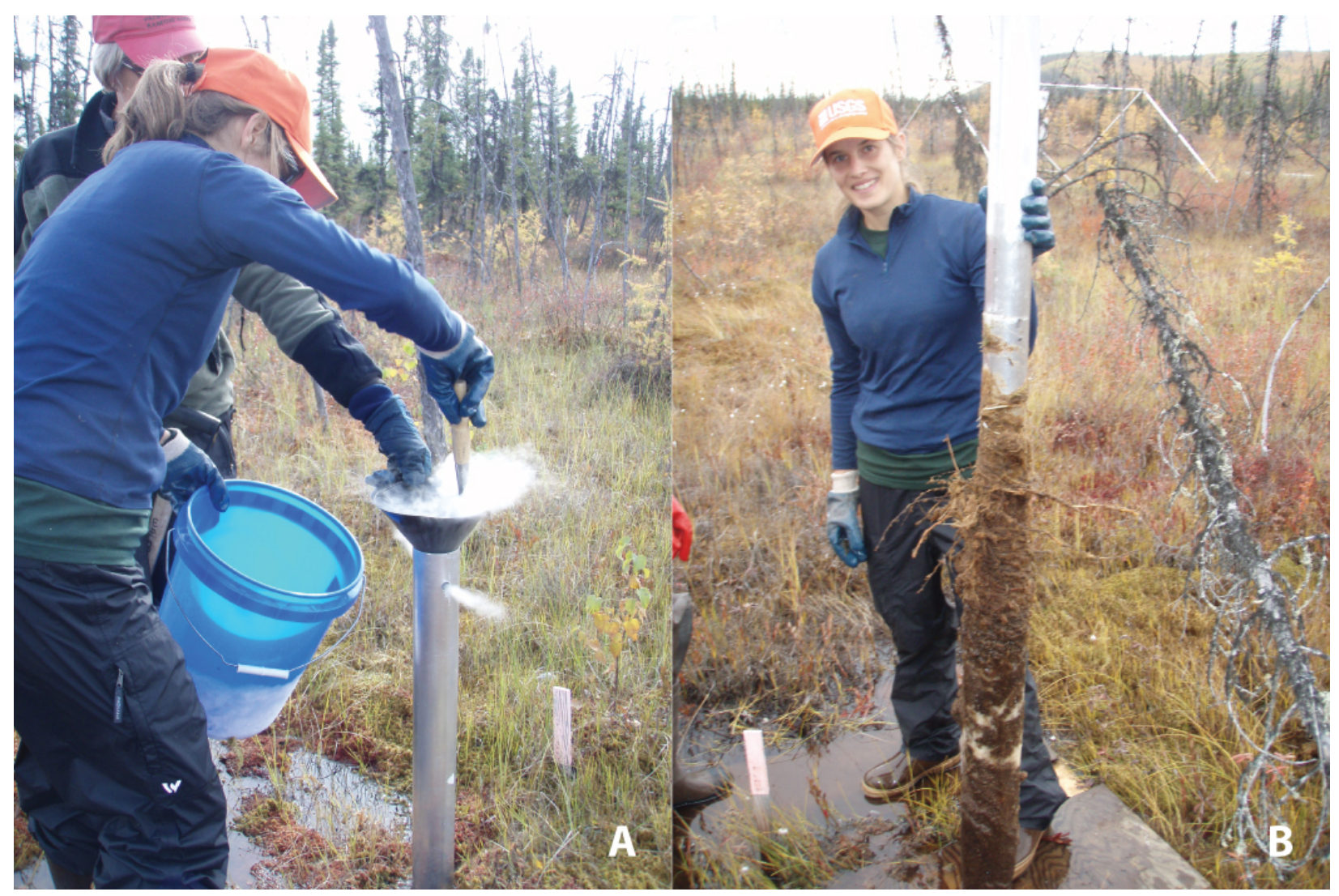

Figure 2. Photograph showing sampling with the frozen finger. A, Pouring in the dry ice-ethanol slurry. $B$, Core with bog material frozen to the outside. 


\section{Soil-Sample Preparation and Drying}

Once each sample arrived at the lab it was split into subsamples; one for bulk density/analytical purposes, another for macrofossils. If additional sample material remained it was preserved as an archive. Bulk density was measured by cutting the sample into either a triangle or square of known dimensions, unless the sample was mostly water, in which case the volume was measured after thawing using a graduated cylinder. Samples were allowed to thaw and were described using the U.S. Department of Agriculture's Natural Resource Conservation Service (USDA-NRCS; Soil Survey Staff, 1998) and Canadian (Soil Classification Working Group, 1998) methodologies with modified descriptive horizon codes according to the following scheme:

L Live moss, which is green and generally contains some leaf and needle litter.

D Dead moss, which is undecomposed or slightly decomposed. This horizon is the upper fibric organic horizon that contains more moss than roots. This horizon would be considered an $\mathrm{O}_{\mathrm{i}}$ horizon (U.S. soil system).

F Fibric (Canadian soil system) or fibrous organic horizon, which varies in the degree of decomposition, but in which roots are more abundant than recognizable plant parts. This horizon would be considered an $\mathrm{O}_{\mathrm{i}}$ horizon (U.S. soil system).

M Mesic (Canadian soil system) organic horizon, which is moderately decomposed, with few, if any, recognizable plant parts other than roots. This horizon is generally considered an $\mathrm{O}_{\mathrm{e}}$ horizon (U.S. soil system).

$\mathrm{H} \quad$ Humic (Canadian soil system) or sapric organic horizon, which is highly decomposed. The soil in this horizon smears when rubbed and contains little to no recognizable plant parts. The $\mathrm{H}$ horizon is generally considered an $\mathrm{O}_{\mathrm{a}}$ horizon (U.S. soil system).

A Upper mineral soil that forms at the surface or just below organic soil horizons (U.S. and Canadian soil systems), which contains less than 20 -volume-percent organic matter, as judged in the field.

B Lower mineral soil that has formed below an A horizon (U.S. and Canadian soil systems), with little or none of its original lithologic structure.

WD Wood. Horizon is comprised of old, decaying wood.

Each soil horizon was labeled with a four-letter code (representing the site), core number, and basal depth of the sample. The first two letters of the site code, BZ, denoted that the samples were from the Bonanza Creek LTER. The third and fourth letters represent the site from which the samples were obtained, Beta-Tower (BT), which indicates they are from the bog with the eddy covariance tower. After the site code, each sample was labeled with a number representing the core. When a frozen finger core was taken from the same location as the SIPRE core (within $1 \mathrm{~m}$ ), that core received the number as the SIPRE core with the letter " $\mathrm{a}$ " added, denoting the additional sampling effort. The first frozen finger core from BZBT 9 did not reach mineral soil; therefore, the corer was reinserted into the same hole and a subsequent sample was obtained. This second core is denoted with the letter "b." After the core number, the sample label is followed by a decimal point and the basal depth of the sample (in centimeters). For example, BZBT 4.41 denotes a sample from soil profile 4, with a basal depth of $41 \mathrm{~cm}$.

The majority of bulk density samples were placed on open shelves in an isolated room and allowed to air-dry to a constant weight. Temperature during air-drying ranged from $20{ }^{\circ} \mathrm{C}$ to $30^{\circ} \mathrm{C}$. The air-drying step was skipped for frozen finger samples. All samples were oven-dried in a forced-draft oven. Samples that were classified as organic soil horizons based on their 
assigned horizon code (for example, moss, fibrics) were oven dried at $65^{\circ} \mathrm{C}$ to avoid loss or alteration of organic matter by oxidation. The remaining samples were oven-dried at $105^{\circ} \mathrm{C}$.

Samples were then processed in one of two ways, depending on horizon code. Mineral soil samples (A and B horizon codes) were gently crushed using a mortar and pestle, with care to break only aggregates, and then sieved through a $2-\mathrm{mm}$ screen. Soil particles that did not pass through the screen were removed, weighed, and saved separately; soil that passed through the screen was ground using a mortar and pestle so that it could pass through a $60-$ mesh $(0.246-\mathrm{mm})$ screen. The ground material was mixed and placed in a labeled glass sample bottle for subsequent analyses. Organic samples were weighed, and roots wider than $1 \mathrm{~cm}$ in diameter were removed, weighed, and saved separately. The remaining sample material was then milled in an Udy Corp. Cyclone Sample Mill to pass through a $0.5-\mathrm{mm}$ screen. The milled samples were thoroughly mixed, and a representative sample was placed in a labeled glass sample bottle for analytical analysis.

\section{Soil Laboratory Methods}

\section{Total Carbon, Total Nitrogen, $\delta^{13} \mathrm{C}$ Measurements}

We analyzed ground soil samples for total C and N using a Carlo Erba NA1500 elemental analyzer. Samples were combusted in the presence of excess oxygen. The resulting sample gases were carried by a continuous flow of helium through an oxidation furnace, followed by a reduction furnace, to yield $\mathrm{CO}_{2}, \mathrm{~N}_{2}$, and water vapor. Water was removed by a chemical trap (usually magnesium perchlorate) and $\mathrm{CO}_{2}$ and $\mathrm{N}_{2}$ were chromatographically separated before the quantification of C and N (Pella, 1990a,b). All samples were compared to a main working standard, ethylene diamine tetra-acetic acid (EDTA). The chemical formula of this compound corresponds to a $\mathrm{C}$ concentration of 41.09 percent and $\mathrm{N}$ concentration of 9.59 percent. Additional working standards were analyzed as samples in all runs to check consistency and overall precision. Peach tree leaves (SRM-1547), issued by the National Institute of Standards and Technology (NIST), were included in runs composed of organic soil. A marine sediment (MESS-1), issued by the Chemistry Division of the Canadian National Research Council, was included in runs composed of mineral soils. Certified values for these standards were obtained from Becker (1990) and Govindaraju (1989), respectively. Average measured values and standard deviations of these working standards are shown in table 1.

Table 1. Statistics of analyses for working standards run on the Carlo Erba 1500, from 2012 to 2014, the time during which these samples were run.

[Certified values: MESS-1, 2.99 percent carbon; SRM-1547, 2.94 percent nitrogen. Stdev., standard deviation; N, number of samples]

\begin{tabular}{lcccccc}
\hline \multirow{2}{*}{ Standard } & \multicolumn{3}{c}{ Percent carbon } & \multicolumn{3}{c}{ Percent nitrogen } \\
\cline { 2 - 7 } & Average & Stdev. & N & Average & Stdev. & N \\
\hline MESS-1 & 2.95 & 0.07 & 24 & 0.20 & 0.01 & 24 \\
SRM-1547 & 46.92 & 0.58 & 98 & 2.86 & 0.10 & 99 \\
\hline
\end{tabular}

\section{Radiocarbon Measurements}

A subset of the macrofossil subsamples had material removed (needles, leaves, seeds, and charcoal), which were analyzed for radiocarbon $\left({ }^{14} \mathrm{C}\right)$ to evaluate the ages of $\mathrm{C}$ in the soil profile. 
These samples were chosen to aid in determining the age of basal organics and areas of transition (in other words, the transition from frozen forest peat to thawed bog peat). The majority of samples were processed at the U.S. Geological Survey (USGS) Radiocarbon Laboratory in Reston, Virginia, and analyzed at the Lawrence Livermore National Laboratory Center for Accelerator Mass Spectrometry (CAMS). Owing to timing, three samples were submitted to Beta Analytic (Miami, Fla.). All USGS/CAMS samples were combusted at $900{ }^{\circ} \mathrm{C}$ in evacuated, sealed quartz tubes in the presence of cupric oxide $(\mathrm{CuO})$ and silver wire. Following cryogenic purification, the $\mathrm{CO}_{2}$ was reduced to graphite using the $\mathrm{H}_{2}$-reduction method at $500-550{ }^{\circ} \mathrm{C}$ (Vogel and others, 1984). Samples processed by Beta Analytic were combusted at $800{ }^{\circ} \mathrm{C}$ under a 100 percent oxygen atmosphere. The resulting $\mathrm{CO}_{2}$ is then dried with methanol/dry ice and collected in liquid $\mathrm{N}$ for the subsequent graphitization reaction. The graphite was produced by hydrogen reduction of the $\mathrm{CO}_{2}$ sample over a cobalt catalyst. Radiocarbon data are reported as $\Delta \Delta^{14} \mathrm{C}$, fraction modern (FM), and radiocarbon age following the conventions of Stuiver and Polach (1977). An aliquot of $\mathrm{CO}_{2}$ from the sample combustion was independently analyzed for $\delta^{13} \mathrm{C}$ to correct for fractionation in each sample.

\section{${ }^{210} \mathrm{~Pb},{ }^{226} \mathrm{Ra}$, and ${ }^{137} \mathrm{Cs}$ Measurements}

Dried and ground subsections of cores were analyzed for ${ }^{210} \mathrm{~Pb},{ }^{226} \mathrm{Ra}$, and ${ }^{137} \mathrm{Cs}$ activities as measured by gamma spectrometry. When the amount of sample available was too low, samples from different horizons were combined proportionally, based on their bulk density. We used a Princeton Gamma High-Purity Germanium (HPGe) well detector to estimate dry-matter accumulation rates for assigning dates to core profiles following methods described in Van Metre and Fuller (2009) and references therein. Briefly, detector efficiency for each isotope was determined using NIST traceable standards $\left({ }^{137} \mathrm{Cs}=\right.$ NBS SRM $4350 \mathrm{~b} ;{ }^{210} \mathrm{~Pb}=$ NBS SRM 4337; ${ }^{226} \mathrm{Ra}=$ NBS SRM 4969). Total ${ }^{210} \mathrm{~Pb}$ activity is the combination of supported ${ }^{210} \mathrm{~Pb}$ (produced within the soil through the decay of ${ }^{226} \mathrm{Ra}$ ) and unsupported ${ }^{210} \mathrm{~Pb}$ (produced in the atmosphere by radon decay and added to the ecosystem through atmospheric deposition). Unsupported ${ }^{210} \mathrm{~Pb}$ was defined as the difference between measured total ${ }^{210} \mathrm{~Pb}$ and ${ }^{226} \mathrm{Ra}$, its long-lived progenitor determined from the activities of ${ }^{214} \mathrm{~Pb}$ and ${ }^{214} \mathrm{Bi}$ gamma-emitting daughters of ${ }^{226} \mathrm{Ra}$. Horizon subsamples from each soil profile were measured until unsupported ${ }^{210} \mathrm{~Pb}$ was no longer detected. Unsupported ${ }^{210} \mathrm{~Pb}$ values can then be used to calculate dry mass accumulation rates (MAR, in grams per cubic centimeter per year) for each soil horizon, from which dates of formation can be calculated (Appleby and Oldfield, 1978).

${ }^{137} \mathrm{Cs}$, an anthropogenic radionuclide (half-life of 30.1 years), provides a means to constrain sediment accumulation rates and chronology because of its well-known input history from atmospheric fallout from aboveground nuclear weapons testing in the 1950s and first half of the 1960s, with maximum deposition occurring during the years 1963 and 1964 (Callender and Robbins, 1993). Measured ${ }^{137} \mathrm{Cs}$ activities were decay corrected for the period of time between sample collection and analysis. Uncertainty in the measured activity of ${ }^{137} \mathrm{Cs}$, ${ }^{210} \mathrm{~Pb}$, and

${ }^{226} \mathrm{Ra}$ was calculated from the counting error of samples and background spectra; uncertainty is reported at the one-standard-deviation level.

\section{Dataset Descriptions}

There are three separate downloadable files containing the soil data collected from the sites described in this report. Appendix 1, found at the end of this document, lists in detail the 
data within the following three spreadsheet files: (1) BZBT_Field, contains field descriptions of the sampled soils, such as root abundance, color, and soil texture; (2) BZBT_Physical contains physical descriptions of the samples, such as volumetric field moisture and bulk density; and (3) BZBT_Chemistry contains elemental C, elemental $\mathrm{N},{ }^{14} \mathrm{C}$, and the radioactive isotope values (in other words, ${ }^{210} \mathrm{~Pb}$ ). The data can be used to calculate how bulk density, root abundance, moisture, and $\mathrm{C}$ and $\mathrm{N}$ storage change by horizon and depth. They can also be used to determine the age of horizon, which in turn can be used to calculate $\mathrm{C}$ and $\mathrm{N}$ accumulation rates. Such data will aid in modeling efforts as well as the analysis of how $\mathrm{C}$ and $\mathrm{N}$ storage changes when a forested permafrost plateau becomes a thermokarst bog.

\section{Acknowledgments}

We thank the Bonanza Creek LTER for allowing us to set up these research sites. Their personnel, especially Jamie Hollingsworth, have been instrumental in this research. Merritt Turetsky aided in site identification and characterization; A. David McGuire supported LTER coordination; Emily Kyker-Snowman and Brittany Johnson assisted with processing samples. We also thank Claire Treat and Meagan Mnich for providing helpful comments on an earlier version of this report. Funding for this work was provided by the National Science Foundation collaborative grant EAR-0630249 and the Climate and Land Use Program.

\section{References Cited}

Appleby, P.G., and Oldfield, F., 1978, The calculation of Lead-210 dates assuming a constant rate of supply of unsupported ${ }^{210} \mathrm{~Pb}$ to the sediment: Catena, v. 5, no. 1, p. 1-8.

Becker, D.A., 1990, Homogeneity and evaluation of the new NIST leaf certified reference materials, in Zeisler, R., and Guinn, V.P., eds., Proceedings of the International Conference on Nuclear Analytical Methods in the Life Sciences: Gaithersburg, MD, National Institute of Standards, p. 571-577.

Callender, E., and Robbins, J.A., 1993, Transport and accumulation of radionuclides and stable elements in a Missouri River reservoir: Water Resources Research, v. 29, no. 6, p. 1787-1804.

Camill, P., Lynch, J.A., Clark, J.S., Adams, J.B., and Jordan, B., 2001, Changes in biomass, aboveground net primary production, and peat accumulation following permafrost thaw in the boreal peatlands of Manitoba, Canada: Ecosystems, v. 4, p. 461-478.

Damman, A.W.H., and French, T.W., 1987, The ecology of peat bogs of the glaciated northeastern United States-A community profile: U.S. Fish and Wildlife Service Biological Report 85, no 7.16, $100 \mathrm{p}$.

Euskirchen, E.S., Edgar, C.W., Turetsky, M.R., Waldrop, M.P., and Harden, J.W., 2014, Differential response of carbon fluxes to climate in three peatland ecosystems that vary in the presence and stability of permafrost: Journal of Geophysical Research-Biogeosciences, v. 119, no. 8, p. 1576-1595.

Gallant, A.L., Binnian, E.F., Omernik, J.M., and Shasby, M.B., 1995, Ecoregions of Alaska: U.S. Geological Survey Professional Paper 1567, 73 p.

Govindaraju, K., 1989, Compilation of working value and sample description for 272 geostandards: Geostandards Newsletter, v. 13, p. 1-113.

Hugelius, G., Strauss, J., Zubrzycki, S., Harden, J.W., Schuur, E.A.G., Ping, C.L., Schirrmeister, L., Grosse, G., Michaelson, G.J., Koven, C.D., O’Donnell, J.A., Elberling, B., Mishra, U., Camill, P., Yu, Z., Palmtag, J., and Kuhry, P., 2014, Estimated stocks of circumpolar 
permafrost carbon with quantified uncertainty ranges and identified data gaps: Biogeosciences, v. 11, no. 23, p. 6573-6593.

Kasischke, E.S., 2000, Boreal ecosystems in the global carbon cycle, in Kasischke, E.S., and Stocks, B.J., eds., Fire, Climate Change, and Carbon Cycling in the Boreal Forest: New York, Springer-Velag, p. 19-30.

Neumann, R.B., Blazewicz, S.J., Conaway, C.H., Turetsky, M.R., and Waldrop, M.P., 2016, Modeling $\mathrm{CH} 4$ and $\mathrm{CO} 2$ cycling using porewater stable isotopes in a thermokarst bog in Interior Alaska — results from three conceptual reaction networks: Biogeochemistry, v. 127, no. 1, p. 57-87.

Pella, E., 1990a, Elemental organic analysis-Part 1-Historical developments: American Laboratory, v. 22, no. 2, p. 116-125.

Pella, E., 1990b, Elemental organic analyzer-Part 2-State of the art: American Laboratory, v. 22 , no. 12 , p. $28-32$.

Rand, J., and Mellor, M., 1985, Ice-coring augers for shallow depth sampling: U.S. Army Cold Regions Research and Engineering Laboratory CRREL Report 85-21, 27 p.

Soil Classification Working Group, 1998, Canadian System of Soil Classification (3rd ed.):

Ontario, National Research Council Canada Research Press, 188 p.

Soil Survey Staff, 1998, Keys to soil taxonomy (8th ed.): Blacksburg, Virginia, Pocahontas Press, $599 \mathrm{p}$.

Stuiver, M., and Polach, H.A., 1977, Discussion reporting of 14C data: Radiocarbon, v. 19, no. 3, p. 355-363.

Tarnocai, C., Canadell, J.G., Schuur, E.A.G., Kuhry, P., Mazhitova, G., and Zimov, S., 2009, Soil organic carbon pools in the northern circumpolar permafrost region: Global Biogeochemical Cycles, v. 23, p. GB2023.

Van Metre, P.C., and Fuller, C.C., 2009, Dual-core mass-balance approach for evaluating mercury and ${ }^{210} \mathrm{~Pb}$ atmospheric fallout and focusing to lakes: Environmental Science \& Technology, v. 43, p. 26-32.

Vogel, J.S., Southon, J.R., Nelson, D.E., and Brown, T.A., 1984, Performance of catalytically condensed carbon for use in accelerator mass spectrometry: Nuclear Instruments and Methods in Physics Research Section B: Beam Interactions with Materials and Atoms, v. 5, no. 2, p. 289-293.

Wickland, K.P., Striegl, R.G., Neff, J.C., and Sachs, T., 2006, Effects of permafrost melting on $\mathrm{CO} 2$ and $\mathrm{CH} 4$ exchange of a poorly drained black spruce lowland: Journal of Geophyiscal Research - Atmospheres, v. 111, p. G02011. 


\section{Appendix 1. Data File Descriptions}

The data files are available online only as Excel (.xlsx) workbooks. The zip file (.zip) containing these files is available at http://dx.doi.org/10.3133/ofr20161173. The content of these files is described in this appendix.

\section{BZBT_Field}

This file contains the field descriptions of the sampled soils. Units for each column are given on row 2 of the file. There are two sheets: one for cores from the thermokarst bog ('Thermokarst') and one with data from the forested permafrost plateau ('Permafrost Plateau'). This file includes the following columns:

\begin{tabular}{|l|l|}
\hline Sample ID & $\begin{array}{l}\text { Sample identification: The first two letters in the sample ID represent the area of study, } \\
\text { Bonanza Creek LTER (BZ). The next two letters represent that the core was taken in or } \\
\text { around the Beta-Tower (BT) site, and are followed by a space. The number that follows } \\
\text { indicates the sample number. A decimal point separates the sample number from the basal } \\
\text { depth of the sample (in centimeters). }\end{array}$ \\
\hline Depth & Indicates the basal depth, in centimeters, of sampling increment. \\
\hline Field horizon code & $\begin{array}{l}\text { Horizon type of the sample, as defined in the field. L, live moss; D, dead moss; F, fibric } \\
\text { organic matter (OM); M, mesic OM; H, humic OM; A, A mineral soil horizon; B, B } \\
\text { mineral soil horizon; WD, wood-dominated soil horizon. For more information about } \\
\text { these horizon types see the Soil-Sample Preparation and Drying section of this report. }\end{array}$ \\
\hline Sample description & $\begin{array}{l}\text { Brief description of the sample. } \\
\text { Root abundance and size using conventions of USDA-NRCS (Soil Survey Staff, 1998). }\end{array}$ \\
\hline Roots & $\begin{array}{l}\text { Munsell color value according to the Munsell Soil Color Chart (http://www.munsell.com), } \\
\text { measured on moist soil. }\end{array}$ \\
\hline Von Post or texture & $\begin{array}{l}\text { If organic soil, the classification using a modified version of the von Post scale of } \\
\text { humification (Damman and French, 1987). If mineral soil, the soil texture class as } \\
\text { described in the field, following conventions of USDA-NRCS (Soil Survey Staff, 1998). }\end{array}$ \\
\hline $\begin{array}{l}\text { Height of each basal depth above the mineral soil boundary. Therefore, the bottom organic } \\
\text { layer equals zero and mineral horizons are negative numbers. } \\
\text { mineral }\end{array}$ & \multicolumn{2}{|l}{} \\
\hline
\end{tabular}




\section{BZBT_Physical}

This file contains physical data such as bulk density and volumetric moisture content. Units for each column are given on row two of the file. There are two worksheets: one for cores from the thermokarst bog ('Thermokarst') and one with data from the forested permafrost plateau ('Permafrost Plateau'). Column definitions are as follows:

\begin{tabular}{|c|c|}
\hline Sample ID & $\begin{array}{l}\text { Sample identification: The first two letters in the sample ID represent the area of study, } \\
\text { Bonanza Creek LTER (BZ). The next two letters represent that the core was taken in or } \\
\text { around the Beta-Tower (BT) site, and are followed by a space. The number that follows } \\
\text { indicates the sample number. A decimal point separates the sample number from the basal } \\
\text { depth of the sample (in centimeters). }\end{array}$ \\
\hline Depth & Indicates the basal depth, in centimeters, of sampling increment. \\
\hline Field horizon code & $\begin{array}{l}\text { Horizon type of the sample, as defined in the field. L, live moss; D, dead moss; F, fibric organic } \\
\text { matter (OM); M, mesic OM; H, humic OM; A, A mineral soil horizon; B, B mineral soil } \\
\text { horizon; WD, wood-dominated soil horizon. For more information about these horizon types } \\
\text { see the Soil-Sample Preparation and Drying section of this report. }\end{array}$ \\
\hline Sample description & Brief description of the sample. \\
\hline Date sampled & Date the sample was taken (month/day/year). \\
\hline Thickness & Thickness of soil horizon. \\
\hline$>2 \mathrm{~mm}$ in sample & Dry weight percent of soil particles not passing through a $2 \mathrm{~mm}$ sieve after gentle crushing. \\
\hline$>1 \mathrm{~cm}$ in sample & Dry weight percent of roots larger than $1 \mathrm{~cm}$ in diameter in the sample. \\
\hline Bulk density & $\begin{array}{l}\text { Grams of oven-dried (OD) soil per cubic centimeter. We do not present bulk density for fine } \\
\text { particles because there were no particles greater than } 2 \mathrm{~mm} \text {, nor roots greater than } 1 \mathrm{~cm} \text { in } \\
\text { diameter. }\end{array}$ \\
\hline $\begin{array}{l}\text { Volumetric field } \\
\text { moisture (OD) }\end{array}$ & The percentage of water in the sample, by volume, of the OD sample. \\
\hline $\begin{array}{l}\text { Moisture in AD } \\
\text { sample }\end{array}$ & $\begin{array}{l}\text { Moisture remaining in a sample after air-drying (AD) to constant weight, as determined by } \\
\text { subsequently oven-drying the sample. Therefore, bulk density, on an air-dried basis, equals } \\
\text { Bulk density }{ }_{\text {oven dry }} /(1-(\text { Convert from AD to OD bulk density/100) }) \text {. }\end{array}$ \\
\hline
\end{tabular}




\section{BZBT_Chemistry}

This file contains analytical data for the samples. Units for each column are given on row 2 of the file. There are two worksheets: one for cores from the thermokarst bog ('Thermokarst') and one with data from the forested permafrost plateau ('Permafrost Plateau'). Column definitions are as follows:

\begin{tabular}{|c|c|}
\hline Sample ID & $\begin{array}{l}\text { Sample identification: The first two letters in the sample ID represent the area of study, } \\
\text { Bonanza Creek LTER (BZ). The next two letters represent that the core was taken in or } \\
\text { around the Beta-Tower (BT) site, and are followed by a space. The number that follows } \\
\text { indicates the sample number. A decimal point separates the sample number from the } \\
\text { basal depth of the sample (in centimeters). }\end{array}$ \\
\hline Depth & Indicates the basal depth, in centimeters, of sampling increment. \\
\hline Field horizon code & $\begin{array}{l}\text { Horizon type of the sample, as defined in the field. L, live moss; D, dead moss; F, fibric } \\
\text { organic matter (OM); M, mesic OM; H, humic OM; A, A mineral soil horizon; B, B } \\
\text { mineral soil horizon; WD, wood-dominated soil horizon. For more information about } \\
\text { these horizon types see the Soil-Sample Preparation and Drying section of this report. }\end{array}$ \\
\hline Sample description & Brief description of the sample. \\
\hline Carbon & $\begin{array}{l}\text { Percentage by weight of total carbon }(\mathrm{C}) \text { in an oven-dried soil sample with material } \\
\text { greater than } 2-\mathrm{mm} \text { or } 1-\mathrm{cm} \text { diameter removed. }\end{array}$ \\
\hline Nitrogen & $\begin{array}{l}\text { Percentage by weight of total nitrogen }(\mathrm{N}) \text { in an oven-dried soil sample with material } \\
\text { greater than } 2-\mathrm{mm} \text { or } 1-\mathrm{cm} \text { diameter removed. }\end{array}$ \\
\hline LOI & $\begin{array}{l}\text { Loss-on-ignition (LOI) value of oven-dried sample with material greater than 2-mm or 1- } \\
\text { cm diameter removed. }\end{array}$ \\
\hline${ }^{137} \mathrm{Cs}$ & Amount of ${ }^{137}$ Cs measured in the sample. \\
\hline${ }^{137} \mathrm{Cs}$ error & Laboratory error associated with the ${ }^{137} \mathrm{Cs}$ measurement (one standard deviation). \\
\hline${ }^{210} \mathrm{~Pb}$ & Amount of ${ }^{210} \mathrm{~Pb}$ measured in the sample. \\
\hline${ }^{210} \mathrm{~Pb}$ error & Laboratory error associated with the ${ }^{210} \mathrm{~Pb}$ measurement (one standard deviation). \\
\hline${ }^{226} \mathrm{Ra}$ & Amount of ${ }^{226} \mathrm{Ra}$ measured in the sample. \\
\hline${ }^{226} \mathrm{Ra}$ error & Laboratory error associated with the ${ }^{226} \mathrm{Ra}$ measurement (one standard deviation). \\
\hline Dating: Lab ID & $\begin{array}{l}\text { Laboratory number for the sample when submitted for }{ }^{14} \mathrm{C} \text { values. Sample numbers in the } \\
\text { form of WW\#\#\#\# are from Lawrence Livermore; ones represented by six numbers are } \\
\text { from Beta Analytic. }\end{array}$ \\
\hline $\begin{array}{l}\text { Dating: fraction } \\
\text { modern }\end{array}$ & Fraction modern (FM) for picked material. \\
\hline Dating: $\pm \mathrm{FM}$ & Analytical error of the fraction modern (FM) value for picked material. \\
\hline Dating: $\Delta^{14} \mathrm{C}$ & $\Delta^{14} \mathrm{C}$ value (\%o) for picked material. \\
\hline Dating: $\pm \Delta^{14} \mathrm{C}$ & Analytical error of $\Delta^{14} \mathrm{C}$ value for picked material. \\
\hline Dating: ${ }^{14} \mathrm{C}$ age & Radiocarbon age (uncorrected) of picked material. \\
\hline Dating: $\pm{ }^{14} \mathrm{C}$ age & Analytical error of radiocarbon age for picked material. \\
\hline Dating Info & Details regarding the type of material that was submitted for ${ }^{14} \mathrm{C}$ dates. \\
\hline
\end{tabular}


ISSN 2331-1258 (online)

http://dx.doi.org/10.3133/ofr20161173 